\title{
A Dynamic Model of the Effects of Feedback-Seeking Behavior and Organizational Commitment on Newcomer Turnover
}

\author{
Journal of Management, in press \\ Christian Vandenberghe \\ HEC Montréal \\ Guylaine Landry \\ Université du Québec à Montréal \\ Kathleen Bentein \\ Université du Québec à Montréal \\ Frederik Anseel \\ Ghent University \& King's College London \\ Karim Mignonac \\ University of Toulouse 1 Capitole \\ Patrice Roussel \\ University of Toulouse 1 Capitole
}

Acknowledgments: We thank editor Christopher O. L. H. Porter and two anonymous reviewers for their valuable feedback and guidance during the review process. This research has been supported by grants from the Canada Research Chairs program to Christian Vandenberghe (No. 950-219143).

Corresponding author: Christian Vandenberghe, HEC Montréal, 3000 chemin Côte SteCatherine, Montréal (Québec), H3T2A7, Canada.

Email: christian.vandenberghe@hec.ca 


\begin{abstract}
Theory and conventional wisdom suggest that progressive reduction of feedback-seeking behavior (FSB) during entry is indicative of work adjustment. We argue that a downside of this process is that newcomers' social integration and acculturation may be weakened. This suggests declining levels of FSB may result in decreased organizational commitment across time and ultimately greater turnover likelihood. These predictions were examined in two longitudinal studies (Study 1: $N=158$; Study 2: $N=170$ ) among newcomers. In both studies, FSB by supervisor inquiry was found to decline across time, and the decrease in FSB preceded a steeper decline in affective organizational commitment. In Study 1, the decline of commitment also resulted in a steeper decrease in FSB. Study 2 further found the decline in commitment to mediate the relationship between the decrease in FSB and increased turnover intention. Finally, increased turnover intention mediated the relationship between the decline in commitment and increased turnover the following year. Bridging research on FSB and organizational commitment, these findings shed new light on the influence of the dynamics of FSB on newcomer turnover.
\end{abstract}

Keywords: feedback-seeking behavior; organizational commitment; turnover; growth/longitudinal modeling. 


\section{A DYNAMIC MODEL OF THE EFFECTS OF FEEDBACK-SEEKING BEHAVIOR} AND ORGANIZATIONAL COMMITMENT ON NEWCOMER TURNOVER

Feedback-seeking behavior (FSB) is defined as "conscious devotion of effort toward determining the correctness and adequacy of behaviors for attaining valued end states" (Ashford, 1986: 466). FSB has attracted considerable attention over the past three decades due to its role as a driver of task performance (e.g., Ashford \& Cummings, 1983; Renn \& Fedor, 2001). In addition to affecting job performance and learning, FSB also influences social acceptance into the organization and adjustment to the workplace, particularly in uncertain and ambiguous situations (Ashford \& Tsui, 1991; Morrison, 1993a). In these situations, FSB can help new employees obtain information that is useful for self-regulating one's behavior in unfamiliar environments. But many questions remain around the nature of FSB's impact on newcomer socialization. This study delves into several of these questions with a focus on how the value of FSB changes over time.

FSB is relevant to newcomers because it facilitates goal attainment (Morrison, 1993a) and reduces uncertainty (Ashford, Blatt, \& VandeWalle, 2003; Berger, 1979). It is among the most important proactive behaviors used during socialization (Bauer, Morrison, \& Callister, 1998; Cooper-Thomas, Paterson, Stadler, \& Saks, 2014; Ellis, Nifadkar, Bauer, \& Erdogan, 2017; Saks \& Ashforth, 1997; Saks, Gruman, \& Cooper-Thomas, 2011). During this period, newcomers face the challenge of learning new skills, making sense of their environment, and adjusting their behavior to become well-integrated employees (Saks et al., 2011). This challenge is particularly salient for those who enter the labor market for the first time $(\mathrm{Ng} \&$ Feldman, 2007). 
As new employees become more familiar with their role and work environment, FSB is expected to decline (e.g., Ashford \& Black, 1996; Ashford et al., 2003; Morrison, 1993a, 2002). Supporting this view, a meta-analysis has reported a negative relationship between FSB and tenure (Anseel, Beatty, Shen, Lievens, \& Sackett, 2015). However, this meta-analysis is based on studies conducted at the between-person level. The few studies that examined FSB longitudinally focused on whether FSB means varied across time but did not track within-person change in FSB (Callister, Kramer, \& Turban, 1999; Morrison, 1993b). The first aim of this paper is to examine the long-standing but untested assumption of an intraindividual decline in FSB during the socialization period. As we will discuss, there are theoretical reasons to expect the rate of decline in FSB to impact employee socialization and retention.

A second objective of this research is to explore how FSB contributes to organizational commitment and turnover, an issue that remains neglected. We draw upon sensemaking theory (Ibarra \& Barbulescu, 2010; Louis, 1980; Weick, 1995; Weick, Sutcliffe, \& Obstfeld, 2005) to argue that FSB has an important role in newcomers' social adjustment. Sensemaking is "the process of social construction in which individuals attempt to interpret and explain sets of cues from their environment" (Maitlis, 2005: 21). From a sensemaking perspective, socialization is a period during which newcomers make sense of who they are becoming as organizational members (Conroy \& O’Leary-Kelly, 2014). During this period, FSB directed at supervisors is important because supervisors provide feedback that reflects organizational expectations (Dahling, Chau, \& O’Malley, 2012; Lam, Peng, Wong, \& Lau, 2017). By seeking such feedback, new employees obtain information about their performance, job expectations, and organizational norms and values, which facilitates social adjustment and integration in the organization (Ashforth, 2001; Ashforth, Harrison, \& Corley, 2008; Ibarra \& Barbulescu, 2010). The drop in 
FSB that presumably happens during socialization (e.g., Morrison, 1993a, 2002) can disrupt sensemaking activities, weakening newcomers' social adjustment. Given the importance of these processes for organizational commitment (e.g., Meyer, Becker, \& Vandenberghe, 2004), a decline in FSB may result in decreased organizational commitment and, ultimately, increased turnover. This implies that organizations would benefit from having their newcomers steadily engage in FSB as a slower decline in feedback-seeking may contribute to reduce turnover.

The present research seeks to make the following contributions. First, we identify an important paradox related to FSB dynamics. The socialization literature assumed that newcomers' proactive behaviors, including FSB (Cooper-Thomas et al., 2014; Saks \& Ashforth, 1997), lead to task mastery and role clarity (e.g., Gong, Wang, Huang, \& Cheung, 2017; Saks \& Ashforth, 1997), hence progressively drop as newcomers master their tasks and clarify their roles. However, from a sensemaking perspective, a decline in FSB may weaken newcomers' social adjustment, which may negatively affect organizational commitment, making it a concern for organizations. Thus, we explore the potential downside of an intraindividual decline in FSB. Second, we build on the idea that "socialization is a dynamic process in which individuals and organizations change over time" (Fisher, 1986: 103) to examine how intraindividual change in FSB contributes to employee turnover. Relying on Chen, Ployhart, Cooper-Thomas, Anderson, and Bliese (2011), we suggest that change in FSB generates information about how newcomers' seeking efforts evolve across time. A decline in FSB would weaken newcomers' understanding of organizational norms and values (Van Maanen \& Schein, 1979; Weick et al., 2005), eventually reducing organizational commitment. This would increase turnover likelihood via increased turnover intention (Bentein, Vandenberg, Vandenberghe, \& Stinglhamber, 2005). 
Third, this paper bridges the streams of research on FSB and organizational commitment by revealing that the dynamics of their relationship is central to the understanding of newcomer turnover. Previous research mainly focused on the relationship between FSB and job performance (e.g., Dahling et al., 2012; Gong et al., 2017; Lam et al., 2017; Payne, Youngcourt, \& Beaubien, 2007) but has rarely examined how FSB affects employee turnover (see Wanberg and Kammeyer-Mueller (2000), for one exception). Based on sensemaking theory, we posit that a decline in FSB disrupts newcomers' understanding of the firm's values, goals and norms, hence weakens the ties with the organization, which in turn affects intended and actual turnover. In the next sections, we discuss the rationale for our model and hypotheses.

\section{WITHIN-PERSON CHANGE IN FSB}

During socialization, newcomers experience a role transition from outsiders to insiders (Bauer, Bodner, Erdogan, Truxillo, \& Tucker, 2007). This period is characterized by uncertainty because the new environment is unfamiliar and role expectations are unknown. New employees are motivated to reduce uncertainty to make their surroundings more predictable (Ashford \& Cummings, 1983; Berger, 1979; Saks \& Ashforth, 1997). They must also learn the behaviors, competencies, and attitudes necessary to meet role expectations (Saks \& Ashforth, 1997). They can reduce uncertainty and meet role expectations by obtaining feedback from internal informants (e.g., co-workers and supervisors) while completing their tasks (Liu, Wang, Bamberger, Shi, \& Bacharach, 2015).

Feedback from organizational insiders such as supervisors is critical to newcomers' adjustment (e.g., Bauer \& Erdogan, 2011; Louis, Posner, \& Powell, 1983; Major, Kozlowski, Chao, \& Gardner, 1995). Supervisors play a central role in newcomers' socialization not only because they facilitate work adjustment, but also because they influence newcomers' future 
prospects in the organization (e.g., Ashford, 1986; Ashford \& Cummings, 1983; Graen, 1976; Miller \& Jablin, 1991; Morrison, 1993a). We focus on feedback inquiry from the supervisor in line with our objective to examine FSB dynamics as a predictor of organizational commitment. Supervisors are organizational agents and have authority over promotion and employment decisions (Webster \& Beehr, 2013), suggesting that feedback gleaned from them has implications for one's career in the organization and commitment to it.

We expect FSB to decrease during socialization. The value of seeking feedback is brought to the forefront in uncertain situations (e.g., the socialization period) because feedback helps new employees learn the skills needed to fulfil their roles and attain performance standards (e.g., Ashford, 1986; Ashford et al., 2003; Park, Schmidt, Scheu, \& DeShon, 2007; Wanberg \& Kammeyer-Mueller, 2000). However, as they become more familiar with their roles, newcomers may reduce their feedback-seeking efforts (Ashford, 1986; Ashford \& Black, 1996; Ashford et al., 2003; Ashford \& Cummings, 1985; Morrison, 1993a, 2002). This is illustrated by a negative association between FSB and job tenure (Anseel et al., 2015). Although this finding is based on studies conducted at the between-person level, a reduction in FSB should also be observed at the intraindividual level. FSB should decline as a result of a learning process, suggesting that task mastery and role clarity, which constitute major challenges during socialization (Morrison, 1993a), are progressively achieved. Thus, we propose the following hypothesis.

Hypothesis 1: Newcomers' trajectory of change in FSB is negative.

\section{WITHIN-PERSON CHANGE IN FSB AND ORGANIZATIONAL COMMITMENT}

A decline in FSB does not necessarily imply that socialization is fully achieved.

Morrison (1993a) argued that the challenges inherent in socialization include: (a) task mastery, which refers to developing the ability to achieve performance outcomes, (b) role clarification, 
which involves getting to know one's role in the organization, (c) acculturation, which implies internalizing the organization's values, and (d) social integration, which refers to socializing with co-workers. As discussed above, FSB's decline may occur when some of these challenges (i.e., task mastery and role clarity) are met through learning. Yet, organizational entry is a passage from outsider to insider (Bauer et al., 2007; Ibarra \& Barbulescu, 2010) that also involves the internalization of cultural norms and values (i.e., acculturation) and the development of social relationships with insiders (Morrison, 1993a). FSB is likely important for meeting these challenges because it helps newcomers know if their behavior is aligned with organizational expectations and socially approved by members of the organization (Ibarra \& Barbulescu, 2010). Moreover, as newcomers are proactive agents of their socialization, they may use FSB to determine if the organization's goals and norms are compatible with their own goals and identity (Conroy \& O’Leary-Kelly, 2014; Dutton, Roberts, \& Bednar, 2010; Lee \& Mitchell, 1994).

The dynamics of FSB should indicate how newcomers' sensemaking activities unfold over time and if social adjustment is achieved. In this study, we use FSB in a broad sense to include the search for feedback about performance but also information relevant to social acceptance as an organizational member (i.e., norms of behavior in the work group, and organizational values and expectations; Morrison, 1993a, 2002). In this process, supervisors act as important providers of feedback and information (Sonenshein, 2010), and may offer cues as to whether newcomers' behavior obtains social approval. When FSB is maintained at high levels, newcomers' behavior is more likely to be rewarded due to effective work adjustment (Ibarra \& Barbulescu, 2010), and the assessment of the compatibility between the organization's goals and norms and one's own goals is facilitated (Lee \& Mitchell, 1994). In contrast, lower levels of FSB over time would reflect social withdrawal and a poor relationship with the supervisor, 
paving the way for a feeling of isolation (Ashforth et al., 2008; Ibarra \& Barbulescu, 2010). In sum, if social feedback is not obtained, newcomers may experience "feelings of social separation, confusion, or alienation" (Kammeyer-Mueller, Wanberg, Rubenstein, \& Song, 2013: 1110).

As FSB has a central role in newcomers' social integration and understanding of organizational norms, it should affect organizational commitment, which "represents a positive attitude toward the organization" (Ashforth et al., 2008: 333). Research has shown that organizational commitment is a major hallmark of newcomers' adjustment and a distal outcome of socialization (e.g., Bauer et al., 2007; Fisher, 1986; Gruman, Saks, \& Zweig, 2006; Ostroff \& Kozlowksi, 1992; Saks et al., 2011). FSB may contribute to organizational commitment through different mechanisms. First, through FSB, newcomers develop a better understanding of the organization's goals, values, and norms, which may enhance organizational commitment (Chao, O’Leary-Kelly, Wolf, Klein, \& Gardner, 1994; Kammeyer-Mueller et al., 2013; Morrison, 1993a). Similarly, feedback-seeking can contribute to organizational commitment through a relationship-building mechanism (Ashford \& Black, 1996; Bauer et al., 2007). Proactive efforts at seeking out feedback may help newcomers reduce feelings of alienation (Kammeyer-Mueller et al., 2013). By seeking feedback, newcomers may also develop a higher quality relationship with the supervisor, which may contribute to organizational commitment though a social exchange mechanism. This is because feedback transmitted by the supervisor is given on behalf of the organization (Rhoades \& Eisenberger, 2002).

Because our research addresses how within-person change in FSB drives change in organizational commitment, it is important to highlight how change across time accounts for the relationship between the two constructs. Drawing upon prospect theory (Kahneman, 
Fredrickson, Schreiber, \& Redelmeier, 1993; Kahneman \& Tversky, 1979, 1984), Chen et al. (2011) showed that a decline in job satisfaction drives an increase in turnover intention. In the present research, we extend this logic to explain how newcomers' decrement in FSB generates a subsequent decline in organizational commitment. The socialization period is a time of uncertainty (e.g., Ashford \& Tsui, 1991; Morrison, 1993a) during which newcomers have a hard time making sense of the cues emanating from their environment (Louis, 1980). Because they lack reference points, newcomers will have to develop relationships with significant others (e.g., the supervisor) to attribute meaning to their experiences and interpret the new setting. In such circumstances, FSB is plausibly a tool for assigning meaning to work experiences.

Based on the socialization literature (Ashford, 1986; Ashford \& Black, 1996; Ashford et al., 2003; Ashford \& Cummings, 1985; Morrison, 1993a, 2002), FSB is expected to decrease within individuals during entry. As newcomers lack interpretive schemes for making sense of their surroundings, FSB and its evolution over time represent a salient mechanism that can be used for self-assessing the process of socialization. From a sensemaking perspective, a downward trend in FSB would compromise the understanding of organizational norms and values, which would affect newcomers' ability to gauge the fit between the organization's culture and their own goals and values (Lee \& Mitchell, 1994). In addition, the decline in FSB makes it difficult for newcomers to be informed about how their social environment perceives and evaluates their behavior. Such process would foster social separation (Kammeyer-Mueller et al., 2013). Finally, a decrease in FSB will likely signal that the quality of the relationship with the supervisor is undermined (Ashford \& Black, 1996; Bauer et al., 2007). The above discussion leads to the following hypothesis. 
Hypothesis 2: The greater the rate of decline in FSB, the greater the decline in organizational commitment.

\section{FSB, COMMITMENT, AND INTENDED AND ACTUAL TURNOVER}

As discussed above, a potential downside of FSB's decline is that social integration is undermined and the understanding of the organization's goals and norms is compromised, leading up to diminished organizational commitment. In turn, organizational commitment is a well-known negative predictor of turnover intention, both at the between-person level (Meyer, Stanley, Herscovitch, \& Topolnytsky, 2002) and at the within-person level (Bentein et al., 2005). Consequently, we expect that those newcomers who engage in less FSB will experience higher turnover intention across time as a result of their reduced organizational commitment. Finally, consistent with research identifying withdrawal cognitions as an immediate precursor of turnover (e.g., Tett \& Meyer, 1993), we expect the increase in turnover intention across time to mediate the relationship between within-person change in organizational commitment and voluntary turnover (Bentein et al., 2005). This leads to the following, remaining hypotheses.

Hypothesis 3: The decline in organizational commitment will mediate the relationship between the decline in FSB and the increase in turnover intention.

Hypothesis 4: The increase in turnover intention will mediate the relationship between the decline in organizational commitment and voluntary turnover.

\section{OVERVIEW OF STUDIES}

To test our hypotheses, we conducted two longitudinal studies with distinct samples of graduates from French universities. Study 1 comprised four measurement times: goal orientations were measured before entry (Time 1) and used as control variables, while FSB and organizational commitment were measured at three consecutive times during the first year of 
employment (Times 2-4). This study provided a first test of Hypotheses 1-2. Study 2 used a similar design but turnover intention was added to Times 2-4 surveys and voluntary turnover data were collected at Time 5 (i.e., one year after Time 4). Study 2 further tested Hypotheses 1-2 and examined Hypotheses 3-4.

\section{STUDY 1}

\section{METHOD}

\section{Sample and Procedure}

The study was conducted on a sample of business and engineering graduates from France. Recruitment was arranged with school officials who informed students about the study. Just before graduation (Time 1, pre-entry), students were surveyed about their goal orientations (see Control variables section) and demographics. They were then surveyed as newcomers at Time 2 and twice more at about 3-month intervals (Times 3 and 4). The time span from Time 2 to Time 4 extended to the first year of employment. Times 2-4 surveys included measures of FSB and organizational commitment. All data were collected through online surveys.

Of the 820 students who were contacted at Time 1, 419 provided usable responses, for a $51 \%$ response rate. Among these participants, 320 responded at Time 2 (about 5 months postentry), 270 at Time 3 (8 months post-entry), and 203 at Time 4 (11 months post-entry). Fortyfive respondents were excluded because they had changed organizations between Time 2 and Time 4, leaving a final sample of 158 employees. In this sample, average age at Time 1 was 24.33 years $(S D=2.70)$, average organizational tenure at Time 2 was 5.50 months $(S D=3.30)$, and $59 \%$ were female. A large majority (97.5\%) were employed full-time; $31.4 \%$ held managerial jobs; 38.0\% worked in large organizations (> 1000 employees), $29.8 \%$ in mid-size organizations (100-1000 employees), and 32.2\% in small organizations ( $<100$ employees). 
Respondents were graduates in different areas of business (e.g., marketing, human resource management, strategy, etc.; 66.5\%) and engineering (e.g., electronics, information systems, aeronautics, etc.; 12.0\%) while the remainder graduated in other disciplines.

To examine subject attrition, we tested whether the probability of remaining in the sample at Time $2(N=320)$, Time $3(N=218)$, and Time $4(N=158)$ among Time 1 respondents $(N=$ 419) could be predicted by control variables (i.e., age, gender and tenure) and FSB and commitment (Goodman \& Blum, 1996). These analyses excluded participants who left their organization between Time 2 and Time 4 . As there were three analyses to perform, we used a Bonferroni adjustment to significance tests to control for Type I error. The models predicting the probability of remaining in the sample at Time $2\left(\chi^{2}[5]=1.75, p=.882\right)$, Time $3\left(\chi^{2}[8]=8.82, p\right.$ $=.357)$, and Time $4\left(\chi^{2}[10]=14.26, p=.162\right)$, were all non-significant and none of the variables were significant. These analyses show that respondent attrition across time was randomly distributed.

\section{Measures}

The study was conducted in French. Scales that were not available in French (i.e., FSB and goal orientations) were translated from English to French using a translation-back-translation procedure (Schaffer \& Riordan, 2003). Unless otherwise specified, a 5-point Likert-type scale (1 = strongly disagree $; 5$ = strongly agree) was used.

FSB. VandeWalle, Ganesan, Challagalla, and Brown's (2000) 5-item scale was used to assess how frequently $(1=$ never; $5=$ very frequently $)$ participants sought feedback from their supervisor regarding their performance, technical aspects of their job, organizational values, expectations with respect to their role, and social norms regarding expected behaviors $(\alpha s=.72$, .81 , and .73 , for Times $2-4$, respectively). 
Organizational commitment. Affective organizational commitment was assessed using Bentein et al.'s (2005) French-adapted version of Meyer, Allen, and Smith's (1993) 6-item scale (e.g., "I really feel that I belong in this organization;" $\alpha$ s $=.89, .90$, and .91 , for Times $2-4$, respectively).

Control variables. As goal orientations are key predictors of FSB (e.g., Anseel et al., 2015; Payne et al., 2007; VandeWalle, 2003; VandeWalle \& Cummings, 1997), particularly during socialization (Morrison, 1993a; Tang, Liu, Oh, \& Weitz, 2014), we incorporated them as predictors of change in FSB. Goal orientations are mental frameworks used to interpret and respond to achievement situations (e.g., Dweck \& Leggett, 1988; Elliott \& Dweck, 1988; Payne et al., 2007; VandeWalle, Brown, Cron, \& Slocum, 1999). There are three main goal orientations (e.g., Payne et al., 2007; VandeWalle, Cron, \& Slocum, 2001): (a) learning goal orientation (LGO), which reflects a preference for learning from experience in order to acquire new competencies; (b) performance-prove goal orientation (PPGO), which focuses on demonstrating one's skills to others; and (c) performance-avoid goal orientation (PAGO), which emphasizes the avoidance of negative judgments about one's competencies. Prior research has reported LGO to be positively, and PAGO negatively, related to FSB (Anseel et al., 2015; Cellar et al., 2011; Payne et al., 2007). VandeWalle et al.'s (2001) LGO (5 items; e.g., "I often look for opportunities to develop new skills and knowledge;" $\alpha=.82$ ), PPGO (4 items; e.g., "I enjoy it when others are aware of how well I am doing;" $\alpha=.76$ ), and PAGO (4 items; e.g., "I prefer to avoid situations where I might perform poorly;" $\alpha=.81$ ) scales were used.

\section{RESULTS}

\section{Descriptive Statistics and Correlations}


Insert Table 1 about here

Descriptive statistics and correlations are reported in Table 1. FSB was positively related to organizational commitment across time.

\section{Latent Growth Modeling Analyses}

Data were examined using latent growth modeling (LGM; e.g., Chan \& Schmitt, 2000;

Lance, Vandenberg, \& Self, 2000). LGM takes measurement error into account and can model complex models of change (Ployhart \& Vandenberg, 2010). LGM uses a structural equation modeling framework to derive two higher-order factors representing the initial status (i.e., intercept) and rate of change (i.e., slope) factors associated with first-order variables assessed multiple times. First, we examined the invariance of FSB and commitment (i.e., first-order variables) across time. Second, we performed nested model comparisons of alternate univariate second-order factor (SOF) LGM models to determine the basic form of change for these variables. Third, we ran an augmented multivariate SOF LGM model to examine the relationships among FSB and commitment's growth parameters. The first two analyses were conducted on the final sample $(N=158)$. For the third analysis, as data attrition across time was random (Ployhart \& Vandenberg, 2010), we used Time 2 respondents (i.e., 320 minus 68 turnover cases; $N=252$ ) and then imputed missing data via the full information maximum likelihood procedure. LGM analyses were conducted using LISREL 8.54 (Jöreskog, Sörbom, Du Toit, \& Du Toit, 2001). The following fit indices were used: the $\chi$ difference test, the comparative fit index (CFI), the nonnormed fit index (NNFI), the standardized root mean square residual (SRMR), and the root mean square error of approximation (RMSEA). 
Measurement invariance. The analysis of measurement invariance was performed via a nested sequence of confirmatory factor analysis (CFA) models. The following sequence of constraints was tested (Vandenberg \& Lance, 2000): (a) equivalent factor structures (i.e., configural invariance); (b) invariance of like items' loadings (i.e., metric invariance); (c) equivalence of item intercepts (i.e., scalar invariance); and (4) invariance of like items' uniquenesses (i.e., invariant uniquenesses). Results are reported in Table 2. Organizational commitment displayed complete longitudinal invariance. FSB achieved configural and metric invariance but neither scalar invariance nor invariant uniquenesses. This was due to (a) the $3^{\text {rd }}$ and $4^{\text {th }}$ item intercepts at Time 4 being significantly different from those at Time 2 and Time 3 , and (b) the uniquenesses of the $3^{\text {rd }}$ item at Time 2 and the $2^{\text {nd }}$ item at Time 4 being significantly greater than the parallel uniquenesses at other times. Thus, the most parsimonious structure for FSB across time included full configural and metric invariance, and partial scalar and uniqueness invariance (Table 2). These specifications were incorporated in LGM analyses.

Insert Table 2 about here

Univariate SOF LGM models. Five alternative SOF LGM models were examined. Model 0 was a no-growth model, Model 1 included linear change and homoscedastic residuals, Model 2 involved linear change and heteroscedastic residuals, while Models 3-4 displayed optimal growth trajectory with homoscedastic (Model 3) vs. heteroscedastic (Model 4) residuals. We compared nested models to determine which model best depicted the variables' change patterns. As shown in Table 3, for commitment, a linear change model (Model 1) was a significant improvement over a no-growth model (Model 0). Moreover, there was no significant 
difference between (a) Model 1 and Model 2, and (b) Model 1 and Model 3. Thus, Model 1 was retained as the best model. For FSB, an optimal change with a homoscedastic structure for residuals (Model 3) did improve model fit and was, consequently, more appropriate.

Insert Tables 3 and 4 about here

Table 4 presents the factor means, variances, and covariances for the univariate SOF LGM models. Consistent with Hypothesis 1, the change factor mean of FSB was significantly negative $\left(\mu_{\mathrm{с}}=-.14, S E=.05, p=.006\right)$, indicating a linear decrease over time. Similarly, organizational commitment declined across time, as shown by a negative change factor mean $\left(\mu_{\text {сн }}\right.$ $=-.15, S E=.03, p=.000)$.

Augmented multivariate SOF LGM model. The relationships among FSB and commitment's growth factors were examined in a multivariate SOF LGM model, controlling for the effects of goal orientations. FSB change was modeled as a predictor of commitment change. We allowed the initial statuses (i.e., intercepts or values at Time 2) of FSB and commitment to covary because previous research suggests these variables are positively related (Payne et al., 2007). The hypothesized SOF LGM model yielded a good fit to the data, $\chi^{2}(607)=1201.73, p$ $=.000, \mathrm{CFI}=.96, \mathrm{NNFI}=.95, \mathrm{SRMR}=.08, \mathrm{RMSEA}=.06$. However, a model in which the path from commitment change to FSB change was additionally freed yielded a better fit, $\Delta \chi^{2}(1)$ $=6.22, p=.013$. Thus, the latter model was retained as the best model.' The growth parameters for this model are reported in Figure 1. 
The path from FSB change to commitment change was significantly positive $(\mathrm{B}=.75, S E$ $=.25, p=.000)$. This indicates that the decline in FSB resulted in a decline in commitment, providing support for Hypothesis 2. The path from commitment change to FSB change was significantly positive as well $(\mathrm{B}=.48, S E=.22, p=.040)$, indicating that the decline in commitment also resulted in a decline in FSB. ${ }^{2}$

\section{DISCUSSION}

Based on a longitudinal study conducted on newcomers, we found evidence for an intraindividual decline in FSB over the first year of employment. A negative change in FSB led to an intraindividual decrease in organizational commitment. However, the decrease in commitment also resulted in a temporal decline in FSB, indicating a reciprocal longitudinal relationship between these variables. Study 2 further explores this relationship and examines how FSB change and commitment change influence employee turnover.

\section{STUDY 2}

\section{METHOD}

\section{Sample and Procedure}

Study 2 data were collected from a separate sample of graduates from French universities. We followed the same procedure as in Study 1, except that we added a turnover intention scale to Times 2-4 surveys and a fifth measurement occasion (Time 5; one year after Time 4), in which we collected information on voluntary turnover. In total, 783 participants responded to the Time 1 survey. Among them, $376(48.0 \%)$ responded at Time 2, $262(69.7 \%)$ at Time 3, $217(82.8 \%)$ at Time 4, and $187(86.2 \%)$ at Time 5. Excluding participants who changed organizations between Time 2 and Time 4, the final sample was 170 at Time 4. From this sample, 149 
individuals responded to the Time 5 turnover survey. Among Time 4 respondents, average age was 24.36 years $(S D=3.86)$ at Time 1 , average tenure was 5.83 months $(S D=4.19)$ at Time 2 , and $63 \%$ were male. Twenty-seven percent of these respondents worked for small organizations (< 100 employees), 30\% for mid-size organizations (100-1000 employees), and $43 \%$ for large organizations (> 1000 employees). Forty-six percent of the participants graduated in engineering while the remainder graduated in different areas of business.

We examined respondent attrition using the same procedure as in Study 1. We tested whether the probability of remaining in the sample at Times 2-5 among Time 1 respondents could be predicted by control variables (i.e., age, gender, tenure and goal orientations) and substantive variables (i.e., FSB, commitment and turnover intention). The models predicting the probability of remaining in the sample at Time $2\left(\chi^{2}[5]=4.09, p=.537\right)$, Time $4\left(\chi^{2}[12]=10.34\right.$, $p=.586)$, and Time $5\left(\chi^{2}[15]=16.28, p=.364\right)$, were all non-significant, and none of the variables were significant. The model predicting the likelihood of responding at Time 3 was significant $\left(\chi^{2}[9]=26.46, p=.002\right)$; tenure was associated with increased probability of responding at Time $3(b=.14, \mathrm{SE}=.04, p=.002)$. In sum, attrition was essentially random.

\section{Measures}

FSB and organizational commitment. We used the same scales as in Study 1 for FSB (Times 2-4 $\alpha \mathrm{s}=.75, .75$, and .81 respectively) and organizational commitment (Times $2-4 \alpha \mathrm{s}=$ $.91, .91$, and .92 , respectively).

Turnover intention. Intention to leave the organization was measured with two items adapted from Hom and Griffeth (1991) (e.g., "I often think about quitting this organization;" $\alpha=$ $.81, .78$, and .86 , for Times $2-4$, respectively). 
Turnover. Stayers were coded as 0; voluntary leavers were coded as 1 . Among the 149 respondents at Time 5, 23 had voluntarily left their organization between Time 4 and Time 5, for a $15.4 \%$ turnover rate.

Control variables. As in Study 1, we controlled for newcomers' pre-entry goal orientations (LGO: $\alpha=$.78; PPGO: $\alpha=.79$; PAGO: $\alpha=.76$ ). Goal orientations were used as predictors of change in FSB.

\section{RESULTS}

\section{Descriptive Statistics and Correlations}

Descriptive statistics and correlations are reported in Table 5. FSB was positively related to commitment across time. Moreover, through Times 2-4, commitment correlated negatively with turnover intention, while turnover intention correlated positively with turnover.

Insert Table 5 about here

\section{LGM Analyses}

Insert Table 6 about here

Measurement invariance. Results of measurement invariance analyses are reported in Table 6. Full longitudinal invariance was achieved for FSB and organizational commitment. For turnover intention, there was full configural, metric, and uniqueness invariances, but partial scalar invariance (the $2^{\text {nd }}$ item intercept from Time 4 was significantly different from the same intercept at Times 2 and 3). These specifications were introduced in the LGM analyses. 
Univariate SOF LGM models. As can been seen from Table 7, a linear change model (Model 1) was the best model for all constructs.

Insert Tables 7 and 8 about here

Table 8 presents the factor means, variances, and covariances for the univariate SOF LGM models. In support of Hypothesis 1 , the change factor mean for FSB was negative $\left(\mu_{\mathrm{cH}}=-\right.$ $.10, S E=.02, p=.000)$, revealing a decline in FSB across time. A similar trend was found for commitment $\left(\mu_{\mathrm{c \mu}}=-.08, S E=.03, p=.001\right)$. For turnover intention, the change factor mean was significantly positive $\left(\mu_{\mathrm{cн}}=.40, S E=.05, p=.000\right)$, indicating an increase over time.

Augmented multivariate FOF LGM model. A multivariate, first-order factor [FOF] LGM model (Figure 2) was specified and tested using Mplus (7.11 version; Muthén \& Muthén, 1998-2012). Because turnover is a binary outcome, we used a robust weighted least squares mean and variance adjusted estimator (WLSMV; Muthén, Du Toit, \& Spisic, 1997). As attrition across time was essentially random, the WLSMV estimator was used to impute Times 3-5 missing data. The model was tested on a sample of 319 respondents (i.e., the Time 2 sample [ $N$ $=376]$ minus those who changed organizations between Time 2 and Time 4 ). We also opted for FOF LGM parameterization to reduce the complexity of our model. FOF LGM models represent the focal constructs through a single composite score obtained by averaging across scale items at each time, and therefore model initial status and change latent variables as first-order factors. As in Study 1, we controlled for the effects of goal orientations on FSB's growth factors. For FSB, commitment, and turnover intention, we fixed the covariance between initial status (i.e., intercept 
or value at Time 2) and rate of change (i.e., slope) at the values obtained in the univariate LGM models.

Insert Figure 2 about here

The hypothesized model fitted the data well: WLSMV $\chi^{2}(216)=305.01, p=.000, \mathrm{CFI}=$ $.91, \mathrm{NNFI}=.89, \mathrm{RMSEA}=.04$. Adding a path from commitment change to FSB change did not improve model fit $\left(\Delta \chi^{2}[1]=.003, p=.956\right)$. Based on the rule of parsimony, the hypothesized model is thus retained for hypotheses testing. ${ }^{3}$ Figure 2 presents the parameter estimates for this model. The decline in FSB resulted in a temporal reduction in organizational commitment $(\mathrm{B}=$ $.83, S E=.24, p=.000)$. Hypothesis 2 is thus further supported. Also, the decrease in commitment led to an increase in turnover intention $(\mathrm{B}=-.53, S E=.14, p=.000)$, and the latter was positively associated with turnover $(\mathrm{B}=.50, S E=.13, p=.000)$. As Hypotheses 3 and 4 addressed mediated relationships, we used a bootstrapping approach to estimate the significance of the relevant indirect effects, a strategy applicable to LGM models (Lockhart, MacKinnon, \& Ohlrich, 2011; MacKinnon, 2008). We bootstrapped 5,000 random samples with replacement from the full sample to obtain $95 \%$ bias-corrected confidence intervals (CIs) for the indirect effects. As predicted in Hypothesis 3, the decline in FSB was negatively related to the increase in turnover intention through the decline in organizational commitment (estimate $=-1.33,95 \%$ $\mathrm{CI}=-4.47,-.37$ ). Finally, as stated in Hypothesis 4, the decline in organizational commitment resulted in higher turnover likelihood through increased turnover intention across time (estimate $=-4.40,95 \% \mathrm{CI}=-13.29,-1.47){ }^{4}$

\section{DISCUSSION}


Findings from Study 2 confirm a negative change in FSB during socialization. This decline in FSB engendered a decline in organizational commitment, but not vice versa. Furthermore, a steeper decline in FSB resulted in increased turnover intention through decreased commitment. This temporal sequence affected employee retention as reduced commitment increased turnover through a rise in turnover intention.

\section{GENERAL DISCUSSION}

In two longitudinal studies, we found consistent evidence that newcomers seek less feedback over time from their supervisor during socialization. Using the tenets of sensemaking theory (Ibarra \& Barbulescu, 2010; Louis, 1980; Weick, 1995), we further expected the dynamics of FSB to influence newcomers' organizational commitment and turnover, a line of inquiry that has been neglected to date. Consistent with this prediction, we found the decline in FSB to result in a subsequent reduction in organizational commitment in both studies, although Study 1 also showed that this relationship was reciprocal. Data from Study 2 further indicated that a decline in FSB contributed to increased turnover intention through a decline in organizational commitment. This temporal sequence then resulted in higher turnover likelihood the following year. These findings cast a new light on the turnover process during socialization by bridging research on FSB (e.g., Anseel et al., 2015; Ashford, 1986; Ashford et al., 2003; Ashford \& Cummings, 1983) and organizational commitment (e.g., Meyer et al., 2004). Implications of these findings for theory and practice are outlined below.

\section{Theoretical Implications}

First, we found that new employees reduce their FSB over time. As the socialization period is characterized by uncertainty (Bauer et al., 2007; Fisher, 1986; Morrison, 1993a; Saks \& Ashforth, 1997), newcomers are motivated to make their environment more predictable (Ashford 
\& Cummings, 1983; Berger, 1979; Saks \& Ashforth, 1997). The decline in FSB indicates that new employees progressively achieve task mastery and clarify their roles (Ashford, 1986; Ashford \& Black, 1996; Ashford et al., 2003; Ashford \& Cummings, 1985; Morrison, 1993a, 2002). This is in line with research showing that the skill level of a new job is predictive of FSB (Wanberg \& Kammeyer-Mueller, 2000). However, the decline in FSB should be interpreted through a broader lens to include acculturation and social integration issues, which represent other socialization challenges (Morrison, 1993a). The FSB measure used in this research focused on organizational values, role expectations and social norms, in addition to task-related aspects (VandeWalle et al., 2000). As FSB was assessed by means of supervisor inquiry, it reflected the idea that (a) individuals have a sense of agency in sensemaking activities, with implications for the acculturation process (Ibarra \& Barbulescu, 2010; Weick et al., 2005), and (b) supervisors are gatekeepers of newcomers' social integration. The decline in FSB suggests that newcomers' acculturation and social integration were plausibly less successful as time passed.

Second, in both studies, the drop in FSB across time precipitated a temporal decline in organizational commitment. This indicates that socialization is a dynamic process (Fisher, 1986), albeit rarely studied as such. This also highlights a paradoxical situation as, on one hand, the progressive reduction of FSB is presumably due to new employees gaining task mastery (Ashford, 1986; Ashford et al., 2003; Ashford \& Cummings, 1983; Morrison, 1993a, 2002), yet on the other hand this very process resulted in a weakening of their attachment to the organization. The paradox may reside in different temporal processes associated with task mastery vs. social integration/acculturation: the latter may take more time to consolidate than the 
former. Therefore, a drop in FSB due to task mastery may be detrimental to social integration and acculturation, and ultimately lead to employee turnover.

We suggested that a decline in FSB may generate a parallel decrease in organizational commitment through different means. First, when FSB through supervisor inquiry decreases, newcomers cannot refine their understanding of the organization's goals, values, and norms (Chao et al., 1994; Kammeyer-Mueller et al., 2013; Morrison, 1993a). This is because supervisors are organizational representatives and important providers of information about the organization (Rhoades \& Eisenberger, 2002). Second, the search for feedback is a powerful relationship-building mechanism (Ashford \& Black, 1996; Bauer et al., 2007). Asking for feedback from one's supervisor allows newcomers to achieve social integration in the work team and larger organization. If such feedback inquiry declines, newcomers may become isolated. Finally, a decline of FSB may signal that the quality of the relationship with the supervisor is less than optimal. This may penalize organizational commitment, given supervisors' central role in the organization. While the above mechanisms are plausible explanations for the relationship between the rate of decline of FSB and the rate of decline of organizational commitment, more research is needed to explore these processes. It is unclear whether this relationship relates primarily to a deficient understanding of organizational norms and values, a lack of social integration, or a poor relationship with the supervisor.

Third, an intriguing finding from Study 1 was that negative change in commitment also resulted in a subsequent decline in FSB. A potential explanation for this is that a downward spiral may occur between FSB and organizational commitment such that once decreases in FSB have significantly reduced organizational commitment, the reduction in commitment may then cause the newcomer to further diminish efforts at seeking feedbacks, and prompt him or her to 
look for a job in another organization. Future research should examine whether job search intervenes in the dynamic relationship between FSB, organizational commitment, and turnover.

Fourth, our results contribute to extend the turnover literature by bridging the streams of research on FSB and organizational commitment. Study 2 found that the decline in organizational commitment mediated the relationship between the decrease in FSB and the increase in turnover intention, which ultimately led to greater turnover likelihood. While previous research had reported a negative association between FSB and actual turnover (Wanberg \& Kammeyer-Mueller, 2000), it had examined the relationship at the between-person level. To the best of our knowledge, the current research is the first to demonstrate that longitudinal change in FSB drives the dynamics of organizational commitment and indirectly contributes to turnover. Moreover, the current findings break new ground by revealing that newcomers' behaviors set the stage for the turnover process. By progressively reducing the search for feedback from their supervisor, newcomers offer observable cues that their attachment to the organization will subsequently drop and increase their turnover likelihood. This finding emphasizes newcomers' sense of agency in building commitment and goes beyond research examining socialization tactics as predictors of embeddedness, commitment and turnover (e.g., Allen, 2006; Allen \& Shanock, 2013). By attending to the relative frequency of newcomers' FSB, supervisors can be informed of employee withdrawal early in the process and act accordingly before the situation worsens. However, doing so requires that they see the dynamics of FSB as an indication of newcomers' social adjustment and not only through the lens of task mastery.

\section{Limitations and Future Research Directions}


First, although we used a longitudinal design to examine the effects of FSB on commitment and retention, survey responses were collected through self-reports. Future research should use multisource data such as having supervisors report on subordinates' FSB frequency (Choi, Moon, \& Nae, 2014; Whitaker \& Levy, 2012) to alleviate the concern for biased self-perceptions. Second, our sample was composed of university graduates entering the job market. The results may not be generalizable to less educated employees or experienced newcomers (i.e., transitioning from one organization to another) who face less uncertainty as they enter the organization (e.g., Bauer et al., 2007) and consequently may use feedback-seeking differently. Third, we hypothesized that the relationship between the decline in FSB and the decrease in commitment can be explained by FSB's role in newcomers' social integration and acculturation. However, these variables were not directly measured. Fourth, alternative explanations for our findings are plausible. For example, the quality of the feedback received may influence the intensity of feedback seeking efforts over time. If newcomers receive poor feedback, they are likely to seek less feedback. Likewise, the efforts at seeking feedback may reflect the quality of the relationship with the supervisor. A poor relationship with the supervisor may discourage FSB, resulting in decreased commitment and more turnover likelihood. Finally, while the relationships among FSB, commitment, and turnover intention were examined across time, it might be worth collecting data on these variables at different time periods which would allow for a stronger examination of their longitudinal relationships. ${ }^{6}$

This study opens interesting avenues for future research. First, an extension of the present work could be to delve into FSB's boundary conditions. For instance, some organizations display a learning culture emphasizing competence development and informationsharing (Tuckey, Brewer, \& Williamson, 2002; van der Rijt, Van den Bossche, van de Wiel, 
Segers, \& Gijselaers, 2012). In these organizations, newcomers may feel encouraged to steadily engage in FSB. In contrast, in organizations characterized by a performance culture, the search for feedback may induce ego-related costs if FSB is interpreted as revealing poor performance (Ashford et al., 2003; Ashford \& Cummings, 1983), thus accelerating FSB's decline.

Second, the present research examined FSB as a global and unitary construct. Future research should examine whether the trajectory of change and effects of feedback-seeking differ across characteristics such as the type of information sought, the FSB strategy (i.e., inquiry vs. monitoring), or the feedback source. For example, newcomers seek information mainly through monitoring (Cooper-Thomas \& Stadler, 2015; Morrison, 1993b). This covert behavior is less costly than direct inquiry to the supervisor (Ashford et al., 2003), hence FSB through monitoring may decline less drastically during entry. Similarly, it would be worth distinguishing the longitudinal effects of FSB related to task mastery from those related to acculturation or social integration (Ellis et al., 2017; Morrison 1993a). Some newcomers may primarily seek feedback about their tasks while others may focus on feedback about organizational goals and values. The former may drive task mastery while the latter may be more relevant to building commitment.

Third, research should explore the role of leader-member exchange in FSB's dynamics as it has been shown to be related to the feedback-seeking process (Chen, Lam, \& Zhong, 2007; Lam et al., 2017; Nifadkar, Tsui, \& Ashforth, 2012). Finally, feedback valence (positive vs. negative) and focus (self vs. others) may be important to consider (Gong et al., 2017). For instance, positive feedback about the self might particularly foster organizational commitment.

\section{Implications for Practice}

Unambiguously, organizations would benefit from having their newcomers constantly engage in feedback-seeking as a slower decline in FSB frequency helps maintain organizational 
commitment and reduce turnover likelihood. One way of encouraging this would be to focus on factors influencing the motives underlying FSB (Tuckey et al., 2002). A supportive feedback environment heightens the instrumental value of seeking feedback (Bose \& Gijselaers, 2013; Dahling, O’Malley, \& Chau, 2015). Supervisors should not only welcome newcomers who solicit feedback but also promote this proactive behavior as supervisors' promotion of feedbackseeking is a strong predictor of FSB frequency (Steelman, Levy, \& Snell, 2004; Whitaker, Dahling, \& Levy, 2007). Supervisors ought to be aware that by promoting the use of feedbackseeking they indirectly facilitate newcomers' social acceptance and loyalty to the organization. Organizations may develop a feedback culture in which individuals continuously solicit feedback to foster development and performance, and enhance commitment (London \& Smither, 2002; Steelman et al., 2004; Whitaker et al., 2007).

Relatedly, reducing the psychological cost of seeking feedback may encourage more frequent FSB (Ashford et al., 2003). This can be achieved by exhibiting consideration to subordinates, establishing a psychologically safe environment, and providing private, constructive, and non-threatening feedback (Kammeyer-Mueller et al., 2013; VandeWalle et al., 2000). While transformational leaders tend to solicit FSB among subordinates (Levy, Cober, \& Miller, 2002), a poor relationship with the feedback source results in feedback avoidance (Vancouver \& Morrison, 1995). Organizations should thus consider offering leadership development activities along these lines. They may also want to include training sessions on feedback-seeking techniques as part of onboarding programs.? This would cultivate a renewed perspective on organizational commitment as reflecting proactive social integration rather than passive reaction to work experiences.

\section{CONCLUSION}


Based on two longitudinal studies with multiple waves of data collection, this research reveals that newcomers' use of FSB through supervisor inquiry declines at the intraindividual level. Negative change in FSB was found to engender a decline in affective organizational commitment. In turn, the latter resulted in increased turnover intention over time, which led to higher turnover likelihood one year later. While scholars have generally portrayed the decline in FSB as an indication of effective work adjustment, the present findings highlight a downside of this process: a reduction in FSB may weaken organizational commitment and be detrimental to retention. We call for more research on this paradox, and more generally, encourage further research on the longitudinal effects of FSB, its boundary conditions and multiple facets. 


\section{REFERENCES}

Allen, D. G. 2006. Do organizational socialization tactics influence newcomer embeddedness and turnover? Journal of Management, 32: 237-256.

Allen, D. G., \& Shanock, L. R. 2013. Perceived organizational support and embeddedness as key mechanisms connecting socialization tactics to commitment and turnover among new employees. Journal of Organizational Behavior, 34: 350-369.

Anseel, F., Beatty, A. S., Shen, W., Lievens, F., \& Sackett, P. R. 2015. How are we doing after 30 years? A meta-analytic review of the antecedents and outcomes of feedback-seeking behavior. Journal of Management, 41: 318-348.

Ashford, S. J. 1986. Feedback-seeking in individual adaptation: A resources perspective. Academy of Management Journal, 29: 465-487.

Ashford, S. J., \& Black, J. S. 1996. Proactivity during organizational entry: The role of desire for control. Journal of Applied Psychology, 81: 199-214.

Ashford, S. J., Blatt, R., \& VandeWalle, D. 2003. Reflections on the looking glass: A review of research on feedback-seeking behavior in organizations. Journal of Management, 29: 773799.

Ashford, S. J., \& Cummings, L. L. 1983. Feedback as an individual resource: Personal strategies of creating information. Organizational Behavior and Human Performance, 32: 370-398.

Ashford, S. J., \& Cummings, L. L. 1985. Proactive feedback seeking: The instrumental use of the information environment. Journal of Occupational Psychology, 58: 67-79.

Ashford, S. J., \& Tsui, S. T. 1991. Self-regulation for managerial effectiveness. Academy of Management Journal, 34: 251-280. 
Ashforth, B. E. 2001. Role transitions in organizational life: An identity-based perspective. Mahwah, NJ: Lawrence Erlbaum Associates.

Ashforth, B. E., Harrison, S. H., \& Corley, K. G. 2008. Identification in organizations: An examination of four fundamental questions. Journal of Management, 34: 325-374.

Bauer, T. N., Bodner, T., Erdogan, B., Truxillo, D. M., \& Tucker, J. S. 2007. Newcomer adjustment during organizational socialization: A meta-analytic review of antecedents, outcomes, and methods. Journal of Applied Psychology, 92: 707-721.

Bauer, T. N., \& Erdogan, B. 2011. Organizational socialization. In S. Zedeck, H. Aguinis, W. Cascio, M. Gelfand, K. Leung, S. Parker \& J. Zhou (Eds.), APA handbook of I/O psychology, vol. 3: 51-64). Washington, DC: APA Press.

Bauer, T. N., Morrison, E. W., \& Callister, R. R. 1998. Organizational socialization: A review and directions for future research. In G. R. Ferris (Ed.), Research in personnel and human resource management: 149-214. Greenwich, CT: JAI Press.

Bentein, K., Vandenberg, R., Vandenberghe, C., \& Stinglhamber, F. 2005. The role of change in the relationship between commitment and turnover: A latent growth modeling approach. Journal of Applied Psychology, 90: 468-482.

Berger, C. R. 1979. Beyond initial interaction: Uncertainty, understanding, and the development of interpersonal relationships. In H. Giles \& R. N. St. Clair (Eds.), Language and social psychology: 122-144. Baltimore, MD: University Park Press.

Bose, M. M., \& Gijselaers, W. H. 2013. Why supervisors should promote feedback-seeking behaviour in medical residency. Medical Teacher, 35: 1573-1583.

Callister, R. R., Kramer, M. W., \& Turban, D. B. 1999. Feedback seeking following career transitions. Academy of Management Journal, 42: 429-438. 
Cellar, D. F., Stuhlmacher, A. F., Young, S. K., Fisher, D. M., Adair, C. K., Haynes, S., Twichell, E., Arnold, K. A., Royer, K., Denning, B. L., \& Riester, D. 2011. Trait goal orientation, self-regulation, and performance: A meta-analysis. Journal of Business and Psychology, 26: 467-483.

Chan, D., \& Schmitt, N. 2000. Inter-individual differences in intra-individual changes in proactivity during organizational entry: A latent growth modeling approach to understanding newcomer adaptation. Journal of Applied Psychology, 85: 190-210.

Chao, G. T., O’Leary-Kelly, A. M., Wolf, S., Klein, H. J., \& Gardner, P. D. 1994. Organizational socialization: Its content and consequences. Journal of Applied Psychology, 79: 730-743.

Chen, G., Ployhart, R. E., Cooper-Thomas, H., Anderson, N., \& Bliese, P. D. 2011. The power of momentum: A new model of dynamic relationships between job satisfaction change and turnover intentions. Academy of Management Journal, 54: 159-181.

Chen, Z., Lam, W., \& Zhong, J. A. 2007. Leader-member exchange and member performance: A new look at individual-level negative feedback-seeking behavior and team-level empowerment climate. Journal of Applied Psychology, 92: 202-212.

Choi, B. K., Moon, H. K., \& Nae, E. Y. 2014. Cognition- and affect-based trust and feedbackseeking behavior: The roles of value, cost, and goal orientations. Journal of Psychology, 148: 603-620.

Conroy, S. A., \& O’Leary-Kelly, A. M. 2014. Letting go and moving on: Work-related identity loss and recovery. Academy of Management Review, 39: 67-87.

Cooper-Thomas, H. D., Paterson, N. L., Stadler, M. J., \& Saks, A. M. 2014. The relative importance of proactive behaviors and outcomes for predicting newcomer learning, wellbeing, and work engagement. Journal of Vocational Behavior, 84: 318-331. 
Cooper-Thomas, H. D., \& Stadler, M. J. 2015. Costs and benefits of newcomer adjustment tactics. International Journal of Selection and Assessment, 23: 160-173.

Dahling, J. J., Chau, S. L., \& O’Malley, A. 2012. Correlates and consequences of feedback orientation in organizations. Journal of Management, 38: 530-545.

Dahling, J., O’Malley, A. L., \& Chau, S. L. 2015. Effects of feedback motives on inquiry and performance. Journal of Managerial Psychology, 30: 199-215.

Dutton, J., Roberts, L. M., \& Bednar, J. 2010. Pathways for positive identity construction at work: Four types of positive identity and the building of social resources. Academy of Management Review, 35: 265-293.

Dweck, C. S., \& Leggett, E. L. 1988. A social-cognitive approach to motivation and personality. Psychological Review, 95: 256-273.

Elliott, E. S., \& Dweck, C. S. 1988. Goals: An approach to motivation and achievement. Journal of Personality and Social Psychology, 54: 5-12.

Ellis, A. M., Nifadkar, S. S., Bauer, T. N., \& Erdogan, B. 2017. Newcomer adjustment: Examining the role of managers' perception of newcomer proactive behavior during organizational socialization. Journal of Applied Psychology, 102: 993-1001.

Fisher, C. D. 1986. Organizational socialization: An integrative review. In K. M. Rowland \& G. R. Ferris (Eds.), Research in personnel and human resources management: 101-145. Greenwich, CT: JAI Press.

Gong, Y., Wang, M., Huang, J.-C., \& Cheung, S. Y. 2017. Toward a goal orientation-based feedback-seeking typology: Implications for employee performance outcomes. Journal of Management, 43: 1234-1260. 
Goodman, J. S., \& Blum, T. C. 1996. Assessing the non-random sampling effects of subject attrition in longitudinal research. Journal of Management, 22: 627-652.

Graen, G. B. 1976. Role making processes within complex organizations. In M. D. Dunnette (Ed.), Handbook of industrial and organizational psychology: 1201-1244. Chicago: Rand McNally.

Gruman, J. A., Saks, A. M., \& Zweig, D. I. 2006. Organizational socialization tactics and newcomer proactive behaviors: An integrative study. Journal of Vocational Behavior, 69: 90104.

Hom, P. W., \& Griffeth, R. W. 1991. Structural equations modeling test of a turnover theory: Cross-sectional and longitudinal analyses. Journal of Applied Psychology, 76: 350-366.

Ibarra, H., \& Barbulescu, R. 2010. Identity as narrative: Prevalence, effectiveness, and consequences of narrative identity work in macro work role transitions. Academy of Management Review, 35: 135-154.

Jöreskog, K. G., Sörbom, D., Du Toit, S., \& Du Toit, M. 2001. LISREL 8: New statistical features. Chicago: Scientific Software International.

Kahneman, D., Fredrickson, B. L., Schreiber, C. A., \& Redelmeier, D. A. 1993. When more pain is preferred to less: Adding a better end. Psychological Science, 4: 401-405.

Kahneman, D., \& Tversky, A. 1979. Prospect theory: An analysis of decisions under risk. Econometrica, 47: 313-327.

Kahneman, D., \& Tversky, A. 1984. Choices, values, and frames. American Psychologist, 39: $341-350$.

Kammeyer-Mueller, J., Wanberg, C., Rubenstein, A., \& Song, Z. 2013. Support, undermining, 
and newcomer socialization: Fitting in during the first 90 days. Academy of Management Journal, 56: 1104-1124.

Lam, L. W., Peng, K. Z., Wong, C.-S., \& Lau, D. C. 2017. Is more feedback seeking always better? Leader-member exchange moderates the relationship between feedback-seeking behavior and performance. Journal of Management, 43: 2195-2217.

Lance, C. E., Vandenberg, R. J., \& Self, R. M. 2000. Latent growth models of individual change: The case of newcomer adjustment. Organizational Behavior and Human Decision Processes, 83: $107-140$.

Lee, T. W., \& Mitchell, T. R. 1994. An alternative approach: The unfolding model of voluntary employee turnover. Academy of Management Review, 19: 51-89.

Levy, P.E., Cober, R. T., \& Miller, T. 2002. The effect of transformational and transactional leadership perceptions on feedback-seeking intentions. Journal of Applied Social Psychology, 32: 1703-1720.

Liu, S., Wang, M., Bamberger, P., Shi, J., \& Bacharach, S. B. 2015. The dark side of socialization: A longitudinal investigation of newcomer alcohol use. Academy of Management Journal, 58: 334-355.

Lockhart, G., MacKinnon, D. P., \& Ohlrich, V. 2011. Mediation analysis in psychosomatic medicine research. Psychosomatic Medicine, 73: 29-43.

London, M., \& Smither, J. 2002. Can working with an executive coach improve multisource feedback ratings over time? A quasi-experimental study. Personnel Psychology, 56: 23-46.

Louis, M. R. 1980. Surprise and sense making: What newcomers experience in entering unfamiliar organizational settings. Administrative Science Quarterly, 25: 226-252. 
Louis, M. R., Posner, B. Z., \& Powell, G. N. 1983. The availability and helpfulness of socialization practices. Personnel Psychology, 36: 857-866.

MacKinnon, D. P. 2008. Introduction to statistical mediation analysis. Mahwah, NJ: Erlbaum.

Maitlis, S. 2005. The social processes of organizational sensemaking. Academy of Management Journal, 48: 21-49.

Major, D. A., Kozlowski, S. W. J., Chao, G. T., \& Gardner, P. D. 1995. A longitudinal investigation of newcomer expectations, early socialization outcomes, and the moderating effects of role development factors. Journal of Applied Psychology, 80: 418-431.

Meyer, J. P., Allen, N. J., \& Smith, C. A. 1993. Commitment to organizations and occupations: Extension and test of a three-component conceptualization. Journal of Applied Psychology, 78: 538-551.

Meyer, J. P., Becker, T. E., \& Vandenberghe, C. 2004. Employee commitment and motivation: A conceptual analysis and integrative model. Journal of Applied Psychology, 89: 991-1007.

Meyer, J. P., Stanley, D. J., Herscovitch, L., \& Topolnytsky, L. 2002. Affective, continuance, and normative commitment to the organization: A meta-analysis of antecedents, correlates, and consequences. Journal of Vocational Behavior, 61: 20-52.

Miller, V. D., \& Jablin, F. M. 1991. Information seeking during organizational entry: Influences, tactics, and a model of the process. Academy of Management Review, 16: 92-120.

Morrison, E. W. 1993a. Longitudinal study of the effects of information seeking on newcomer socialization. Journal of Applied Psychology, 78: 173-183.

Morrison, E. W. 1993b. Newcomer information-seeking: Exploring types, modes, sources, and outcomes. Academy of Management Journal, 36: 557-589. 
Morrison, E. W. 2002. Information seeking within organizations. Human Communication Research, 28: 229-242.

Muthén, B., Du Toit, S., \& Spisic, D. 1997. Robust inference using weighted least squares and quadratic estimating equations in latent variable modeling with categorical and continuous outcomes. Unpublished manuscript.

Muthén, L., \& Muthén, B. 1998-2012. Mplus user’s guide. Los Angeles: Muthén \& Muthén.

Ng, T. W. H., \& Feldman, D. C. 2007. The school-to-work transition: A role identity perspective. Journal of Vocational Behavior, 71: 114-134.

Nifadkar, S. S., Tsui, A. S., \& Ashforth, B. E. 2012. The way you make me feel (and behave): Newcomer affect and approach-avoidance behavior toward the supervisor. Academy of Management Journal, 55: 1146-1168.

Ostroff, C., \& Kozlowski, S. W. J. 1992. Organizational socialization as a learning process: The role of information acquisition. Personnel Psychology, 45: 849-874.

Park, G., Schmidt, A. M., Scheu, C., \& DeShon, R. P. 2007. A process model of goal orientation and feedback seeking. Human Performance, 20: 119-145.

Payne, S. C., Youngcourt, S. S., \& Beaubien, J. M. 2007. A meta-analytic examination of the goal orientation nomological net. Journal of Applied Psychology, 92: 128-150.

Ployhart, R. E., \& Vandenberg, R. J. 2010. Longitudinal research: The theory, design, and analysis of change. Journal of Management, 36: 94-120.

Renn, R. W., \& Fedor, D. B. 2001. Development and field test of a feedback seeking, selfefficacy, and goal setting model of work performance. Journal of Management, 27: 563-583.

Rhoades, L., \& Eisenberger, R. 2002. Perceived organizational support: A review of the 
literature. Journal of Applied Psychology, 87: 698-714.

Saks, A. M., \& Ashforth, B. E. 1997. Organizational socialization: Making sense of the past and present as a prologue for the future. Journal of Vocational Behavior, 51: 234-279.

Saks, A. M., Gruman, J. A., \& Cooper-Thomas, H. 2011. The neglected role of proactive behavior and outcomes in newcomer socialization. Journal of Vocational Behavior, 79: 3646.

Schaffer, B. S., \& Riordan, C. M. 2003. A review of cross-cultural methodologies for organizational research: A best-practices approach. Organizational Research Methods, 6: 169-215.

Sonenshein, S. 2010. We're changing or are we? Untangling the role of progressive, regressive, and stability narratives during strategic change implementation. Academy of Management Journal, 53 : 477-512.

Steelman, L. A., Levy, P. E., \& Snell, A. F. 2004. The feedback environment scale: Construct definition, measurement, and validation. Educational and Psychological Measurement, 64: 165-184.

Tang, C., Liu, Y., Oh, H., \& Weitz, B. 2014. Socialization tactics of new retail employees: A pathway to organizational commitment. Journal of Retailing, 90: 62-73.

Tett, R. P., \& Meyer, J. P. 1993. Job satisfaction, organizational commitment, turnover intention, and turnover: Path analyses based on meta-analytic findings. Personnel Psychology, 46: 259293.

Tisak, J., \& Meredith, W. 1990. Descriptive and associative developmental models. Statistical methods in longitudinal research, vol. 2: 387-406. Boston: Academic Press. 
Tuckey, M., Brewer, N., \& Williamson, P. 2002. The influence of motives and goal orientation on feedback seeking. Journal of Occupational and Organizational Psychology, 75: 195-216.

Vancouver, J. B., \& Morrison, E. W. 1995. Feedback inquiry: The effect of source attributes and individual differences. Organizational Behavior and Human Decision Processes, 62: 276285.

Vandenberg, R. J., \& Lance, C. E. 2000. A review and synthesis of measurement invariance literature: Suggestions, practices, and recommendations for organizational research. Organizational Research Methods, 3: 4-70.

VandeWalle, D. 2003. A goal orientation model of feedback-seeking behavior. Human Resource Management Review, 13: 581-604.

VandeWalle, D., Brown, S. P., Cron, W. L., \& Slocum Jr, J. W. 1999. The influence of goal orientation and self-regulation tactics on sales performance: A longitudinal field test. Journal of Applied Psychology, 84: 249-259.

VandeWalle, D., Cron, W. L., \& Slocum Jr, J. W. 2001. The role of goal orientation following performance feedback. Journal of Applied Psychology, 86: 629-640.

VandeWalle, D., \& Cummings, L. L. 1997. A test of the influence of goal orientation on the feedback-seeking process. Journal of Applied Psychology, 82: 390-400.

VandeWalle, D., Ganesan, S., Challagalla, G. N., \& Brown, S. P. 2000. An integrated model of feedback-seeking behavior: Disposition, context and cognition. Journal of Applied Psychology, 85: 996-1003.

van der Rijt, J., Van den Bossche, P., van de Wiel, M. W. J., Segers, M. S. R., \& Gijselaers, W. H. 2012. The role of individual and organizational characteristics in feedback-seeking behavior in the initial career stage. Human Resource Development International, 15: 283-301. 
Van Maanen, J., \& Schein, E. H. 1979. Toward a theory of organizational socialization. Research in Organizational Behavior, 1: 209-264.

Wanberg, C. R., \& Kammeyer-Mueller, J. D. 2000. Predictors and outcomes of proactivity in the socialization process. Journal of Applied Psychology, 85: 373-385.

Webster, J. R., \& Beehr, T. A. 2013. Antecedents and outcomes of employee perceptions of intra-organizational mobility channels. Journal of Organizational Behavior, 34: 919-941.

Weick, K. E. 1995. Sensemaking in organizations. Thousand Oaks, CA: Sage.

Weick, K. E., Sutcliffe, K. M., \& Obstfeld, D. 2005. Organizing and the process of sensemaking. Organization Science, 16: 409-421.

Whitaker, B. G., Dahling, J. J., \& Levy, P. 2007. The development of a feedback environment and role clarity model of job performance. Journal of Management, 33: 570-591.

Whitaker, B. G., \& Levy, P. 2012. Linking feedback quality and goal orientation to feedback seeking and job performance. Human Performance, 25: 159-178. 


\section{FOOTNOTES}

'Note that adding a path between the control variables (i.e., goal orientations) and change in organizational commitment resulted in a non-significant improvement of model fit, $\Delta \chi^{2}(3)=$ $1.09, p=.779$, and none of the paths were significant.

${ }^{2}$ For exploratory purposes, we added gender, age, and organizational tenure as demographic variables that could affect the rate of change in FSB. That model yielded a good fit to the data, $\chi^{2}(705)=1303.49, p=.000, \mathrm{CFI}=.95, \mathrm{NNFI}=.95, \mathrm{RMSEA}=.06$. Yet, the paths from these variables to change in FSB were all non-significant. Similarly, a model that included gender, age, and organizational tenure as additional predictors of change in organizational commitment yielded a good fit to the data, $\chi^{2}(705)=1306.17, p=.000, \mathrm{CFI}=.95, \mathrm{NNFI}=.95$, RMSEA $=.06$, but the paths from these variables to change in organizational commitment were all non-significant.

${ }^{3}$ Adding a path between the control variables (i.e., goal orientations) and change in organizational commitment resulted in a non-significant improvement of model fit, $\Delta \chi^{2}(3)=$ $4.43, p=.219$, and none of the paths were significant.

${ }^{4}$ We also tested whether gender, age, and organizational tenure could affect the rate of change in FSB in the final multivariate LGM model. This model yielded a moderate fit to the data, $\chi^{2}(282)=405.07, p=.000, \mathrm{CFI}=.88, \mathrm{NNFI}=.86, \mathrm{RMSEA}=.04$, and the paths from these variables to change in FSB were all non-significant. Similarly, we examined a model where the same variables predicted the rate of change in organizational commitment. This model yielded a moderate fit to the data, $\chi^{2}(282)=392.96, p=.000, \mathrm{CFI}=.89, \mathrm{NNFI}=.87, \mathrm{RMSEA}=.04$, and the corresponding paths were all non-significant.

${ }^{5}$ We thank an anonymous reviewer for suggesting this interpretation. 
${ }^{6}$ We thank an anonymous reviewer for suggesting these alternative explanations for our results and the longitudinal extension of our research.

${ }^{\urcorner}$We thank an anonymous reviewer for suggesting this practical implication. 
Table 1

Study 1: Descriptive Statistics and Correlations among Variables

\begin{tabular}{|c|c|c|c|c|c|c|c|c|c|c|c|c|c|c|}
\hline Variable & $M$ & $S D$ & 1 & 2 & 3 & 4 & 5 & 6 & 7 & 8 & 9 & 10 & 11 & 12 \\
\hline 1. Gender (T1) & 1.41 & 0.49 & - & & & & & & & & & & & \\
\hline 2. Age (years) (T1) & 24.33 & 2.70 & .14 & - & & & & & & & & & & \\
\hline 3. Organizational tenure (months) (T2) & 5.50 & 3.30 & .03 & .09 & - & & & & & & & & & \\
\hline 4. $\mathrm{LGO}(\mathrm{T} 1)$ & 4.17 & 0.54 & .06 & .14 & -.03 & .82 & & & & & & & & \\
\hline 5. $\mathrm{PPGO}(\mathrm{T} 1)$ & 3.67 & 0.75 & .15 & -.05 & -.07 & $.29^{* *}$ & .76 & & & & & & & \\
\hline 6. PAGO (T1) & 2.40 & 0.85 & .07 & .09 & -.02 & $-.36 * *$ & $.23^{* *}$ & .81 & & & & & & \\
\hline 7. FSB (T2) & 3.01 & 0.69 & .01 & -.08 & -.13 & .06 & .06 & -.03 & .72 & & & & & \\
\hline 8. FSB (T3) & 2.80 & 0.83 & .06 & -.07 & -.03 & .05 & $.20 *$ & -.08 & $.49 * *$ & .81 & & & & \\
\hline 9. FSB (T4) & 2.60 & 0.73 & .09 & -.08 & .12 & .01 & .08 & .03 & $.25^{* *}$ & $.42^{* *}$ & .73 & & & \\
\hline 10. Organizational commitment (T2) & 3.48 & 0.88 & -.07 & -.13 & -.08 & .06 & .14 & -.13 & $.28^{* *}$ & $.29^{* *}$ & $.23 * *$ & .89 & & \\
\hline 11. Organizational commitment (T3) & 3.35 & 0.91 & -.07 & -.16 & .07 & .10 & .10 & $-.19 *$ & $.22 * *$ & $.40^{* *}$ & $.27^{* *}$ & $.72 * *$ & .90 & \\
\hline 12. Organizational commitment (T4) & 3.17 & 1.02 & -.09 & -.16 & .05 & .05 & .12 & -.09 & $.24^{* *}$ & $.35^{* *}$ & $.36^{* *}$ & $.69^{* *}$ & $.81^{* *}$ & .91 \\
\hline
\end{tabular}

Note. $N=158 . \mathrm{T} 1=$ Time $1 ; \mathrm{T} 2=$ Time $2 ; \mathrm{T} 3=$ Time $3 ; \mathrm{T} 4=$ Time $4 ; \mathrm{LGO}=$ Learning goal orientation; PPGO = Performance-prove goal orientation; PAGO = Performance-avoid goal orientation; FSB = Feedback-seeking behavior; For Gender: $1=$ Female, $2=$ Male. Alpha coefficients are reported in bold along the diagonal.

$* p<.05$

$* * p<.01$ 
Table 2

Study 1: Tests of Measurement Invariance

\begin{tabular}{|c|c|c|c|c|c|c|c|c|c|}
\hline & & $\chi^{2}$ & $d f$ & CFI & NNFI & SRMR & RMSEA & $\begin{array}{c}\text { Model } \\
\text { comparison }\end{array}$ & $\Delta \chi^{2}(\Delta d f) / p$ \\
\hline \multirow[t]{6}{*}{ FSB } & 1. Equivalent factor structures & 151.09 & 72 & .95 & .93 & .08 & .08 & & \\
\hline & 2. Equal factor loadings & 158.60 & 80 & .95 & .94 & .08 & .08 & 2 vs. 1 & $7.51(8) / .483$ \\
\hline & 3. Equal intercepts & 184.39 & 88 & .94 & .93 & .09 & .09 & 3 vs. 2 & $25.79(8) / .001$ \\
\hline & 4. Equal uniquenesses & 212.03 & 98 & .93 & .93 & .10 & .09 & 4 vs. 3 & $27.64(10) / .002$ \\
\hline & 3a. Partially equivalent intercepts & 165.70 & 86 & .95 & .94 & .08 & .08 & 3a vs. 2 & $7.1(6) / .312$ \\
\hline & $\begin{array}{l}\text { 4a. Partially equivalent intercepts and } \\
\text { partially equivalent uniquenesses }\end{array}$ & 179.86 & 94 & .95 & .94 & .09 & .08 & $4 a$ vs. $3 a$ & $14.16(8) / .078$ \\
\hline \multirow[t]{4}{*}{ Organizational commitment } & 1. Equivalent factor structures & 188.72 & 114 & .99 & .99 & .05 & .06 & & \\
\hline & 2. Equal factor loadings & 195.99 & 124 & .99 & .99 & .05 & .06 & 2 vs. 1 & $7.27(10) / .670$ \\
\hline & 3. Equal intercepts & 212.57 & 134 & .99 & .99 & .05 & .06 & 3 vs. 2 & $16.58(10) / .084$ \\
\hline & 4. Equal uniquenesses & 221.54 & 146 & .99 & .99 & .05 & .05 & 4 vs. 3 & $8.97(12) / .705$ \\
\hline
\end{tabular}

Note. FSB = Feedback-seeking behavior; $\mathrm{CFI}=$ Comparative fit index; NNFI = Nonnormed fit index; $\mathrm{SRMR}=\mathrm{Standardized}$ root mean square residual; RMSEA = Root mean square error of approximation. 
Table 3

Study 1: Univariate Second-Order Factor Latent Growth Models: Tests of Alternative Specifications

\begin{tabular}{|c|c|c|c|c|c|c|c|c|c|}
\hline & & $\begin{array}{l}\text { Change } \\
\text { function }\end{array}$ & $\begin{array}{c}\text { FOF residuals } \\
\text { structure }\end{array}$ & $\chi^{2}$ & $d f$ & CFI & NNFI & SRMR & RMSEA \\
\hline \multirow[t]{3}{*}{ FSB } & Model 0 & No Change & & 203.14 & 98 & .94 & .93 & .11 & .08 \\
\hline & Model 2 & Linear & Heteroscedastic & 187.13 & 95 & .95 & .94 & .09 & .08 \\
\hline & Model 3a & Optimal & Homoscedastic & 183.86 & 96 & .95 & .94 & .09 & .08 \\
\hline \multirow[t]{5}{*}{ Organizational commitment } & Model 0 & No Change & & 259.32 & 150 & .98 & .98 & .09 & .06 \\
\hline & Model 1 $1^{\mathrm{a}}$ & Linear & Homoscedastic & 224.42 & 149 & .99 & .99 & .05 & .05 \\
\hline & Model 2 & Linear & Heteroscedastic & 221.97 & 147 & .99 & .99 & .05 & .05 \\
\hline & Model 3 & Optimal & Homoscedastic & 224.39 & 148 & .99 & .99 & .05 & .05 \\
\hline & Model 4 & Optimal & Heteroscedastic & 246.52 & 146 & .99 & .99 & .05 & .06 \\
\hline
\end{tabular}

Note. FSB $=$ Feedback-seeking behavior; $\mathrm{CFI}=$ Comparative fit index; NNFI $=$ Nonnormed fit index; SRMR $=$ Standardized root mean square residual; RMSEA = Root mean square error of approximation.

a Retained (most parsimonious) model. 
Table 4

Study 1: Univariate Second-Order Factor Latent Growth Models: Growth Parameters Estimates

\begin{tabular}{|c|c|c|c|c|c|}
\hline & \multicolumn{2}{|c|}{ Initial Status (IS) } & \multicolumn{2}{|c|}{ Change $(\mathrm{CH})$} & \multirow[b]{2}{*}{ Covariance IS-CH } \\
\hline & Mean & Variance & Mean & Variance & \\
\hline Variable / Parameter & $\left(\mu_{\text {is }}\right)$ & $\left(\sigma^{2}{ }_{\mathrm{IS}}\right)$ & $\left(\mu_{\text {сн }}\right)$ & $\left(\sigma_{\mathrm{CH}}^{2}\right)$ & $\left(\sigma_{\mathrm{ISCH}}\right)$ \\
\hline FSB (optimal \& homoscedastic) & $3.06 * * *$ & $.07 *$ & $-.14 * *$ & .04 & .05 \\
\hline Organizational commitment & $3.75 * * *$ & $.54 * * *$ & $-.15 * * *$ & $.06 * *$ & .01 \\
\hline
\end{tabular}

Note . FSB = Feedback-seeking behavior. Standardizing the manifest variables impedes the ability to examine change because the standardization equates the means and variances (Tisak \& Meredith, 1990); therefore, unstandardized estimates are reported.

$* p<.05$

$* * p<.01$

$* * * p<.001$ 


\section{Table 5}

Study 2: Descriptive Statistics and Correlations among Variables

\begin{tabular}{|c|c|c|c|c|c|c|c|c|c|c|c|c|c|c|c|c|c|}
\hline Variable & $M$ & $S D$ & 1 & 2 & 3 & 4 & 5 & 6 & 7 & 8 & 9 & 10 & 11 & 12 & 13 & 14 & 15 \\
\hline 1. Gender (T1) & 1.63 & 0.48 & - & & & & & & & & & & & & & & \\
\hline 2. Age (years) (T1) & 24.36 & 3.86 & -.09 & - & & & & & & & & & & & & & \\
\hline 3. Org. tenure (months) (T2) & 5.83 & 4.19 & -.04 & $.42 * *$ & - & & & & & & & & & & & & \\
\hline 4. $\mathrm{LGO}(\mathrm{T} 1)$ & 4.16 & 0.55 & -.11 & $.16^{*}$ & .07 & .78 & & & & & & & & & & & \\
\hline 5. $\mathrm{PPGO}(\mathrm{T} 1)$ & 3.48 & 0.82 & -.01 & -.02 & .04 & $.26^{* *}$ & .79 & & & & & & & & & & \\
\hline 6. PAGO (T1) & 2.45 & 0.80 & $.15^{*}$ & .02 & .10 & $-.30 * *$ & $.16^{*}$ & .76 & & & & & & & & & \\
\hline 7. FSB (T2) & 2.62 & 0.70 & -.10 & -.09 & -.09 & .02 & .07 & .00 & .75 & & & & & & & & \\
\hline 8. FSB (T3) & 2.49 & 0.71 & -.09 & -.01 & .06 & .03 & .10 & .04 & $.55^{* *}$ & .75 & & & & & & & \\
\hline 9. FSB (T4) & 2.37 & 0.74 & .02 & .04 & .08 & .08 & .00 & .03 & $.50 * *$ & $.57 * *$ & .81 & & & & & & \\
\hline 10. Org. commitment (T2) & 3.09 & 0.93 & -.09 & $-.18^{*}$ & .13 & $.15^{*}$ & $.17 *$ & -.11 & $.20^{* *}$ & $.26 * *$ & $.16^{*}$ & .91 & & & & & \\
\hline 11. Org. commitment (T3) & 3.03 & 0.95 & -.07 & -.10 & $.16^{*}$ & .12 & $.20 * *$ & -.08 & .15 & $.28 * *$ & $.20 * *$ & $.78 * *$ & .91 & & & & \\
\hline 12. Org. commitment (T4) & 2.93 & 0.95 & -.03 & -.08 & $.17 *$ & .10 & .13 & -.05 & $.17^{*}$ & $.21 * *$ & $.28 * *$ & $.76^{* *}$ & $.81^{* *}$ & .92 & & & \\
\hline 13. Turnover intention (T2) & 2.19 & 1.20 & .01 & $.27 * *$ & $.19 *$ & .00 & -.13 & .06 & -.10 & -.08 & -.01 & $-.44 * *$ & $-.33 * *$ & $-.30 * *$ & .81 & & \\
\hline 14. Turnover intention (T3) & 2.54 & 1.18 & -.02 & $.17^{*}$ & .11 & .03 & -.07 & .02 & .04 & -.04 & -.04 & $-.36 * *$ & $-.39 * *$ & $-.32 * *$ & $.64 * *$ & .78 & \\
\hline 15. Turnover intention (T4) & 2.90 & 1.33 & -.01 & .02 & .02 & .07 & -.01 & -.06 & .01 & -.05 & -.11 & $-.31 * *$ & $-.26 * *$ & $-.37 * *$ & $.56^{* *}$ & $.72 * *$ & .86 \\
\hline 16. Turnover (T5) & 0.15 & 0.36 & -.11 & -.05 & .04 & .04 & .05 & -.08 & .10 & .04 & -.01 & -.11 & -.02 & $-.17 *$ & $.19 *$ & $.27 * *$ & $.38 * *$ \\
\hline
\end{tabular}

Note. $\mathrm{Ns}=170$ (all correlations except those involving turnover) and 149 (correlations with turnover). T1 = Time 1; T2 = Time 2; T3 = Time 3; T4 = Time 4; T5 = Time 5; Org. tenure = Organizational tenure LGO = Learning goal orientation; PPGO = Performanceprove goal orientation; PAGO $=$ Performance-avoid goal orientation; FSB $=$ Feedback-seeking behavior; Org. commitment $=$ Organizational commitment. For Gender: $1=$ Female, $2=$ Male; for Turnover: $0=$ Stay, $1=$ Voluntary turnover. Alpha coefficients are reported in bold along the diagonal.

$* p<.05$

$* * p<.01$ 
Table 6

Study 2: Tests of Measurement Invariance

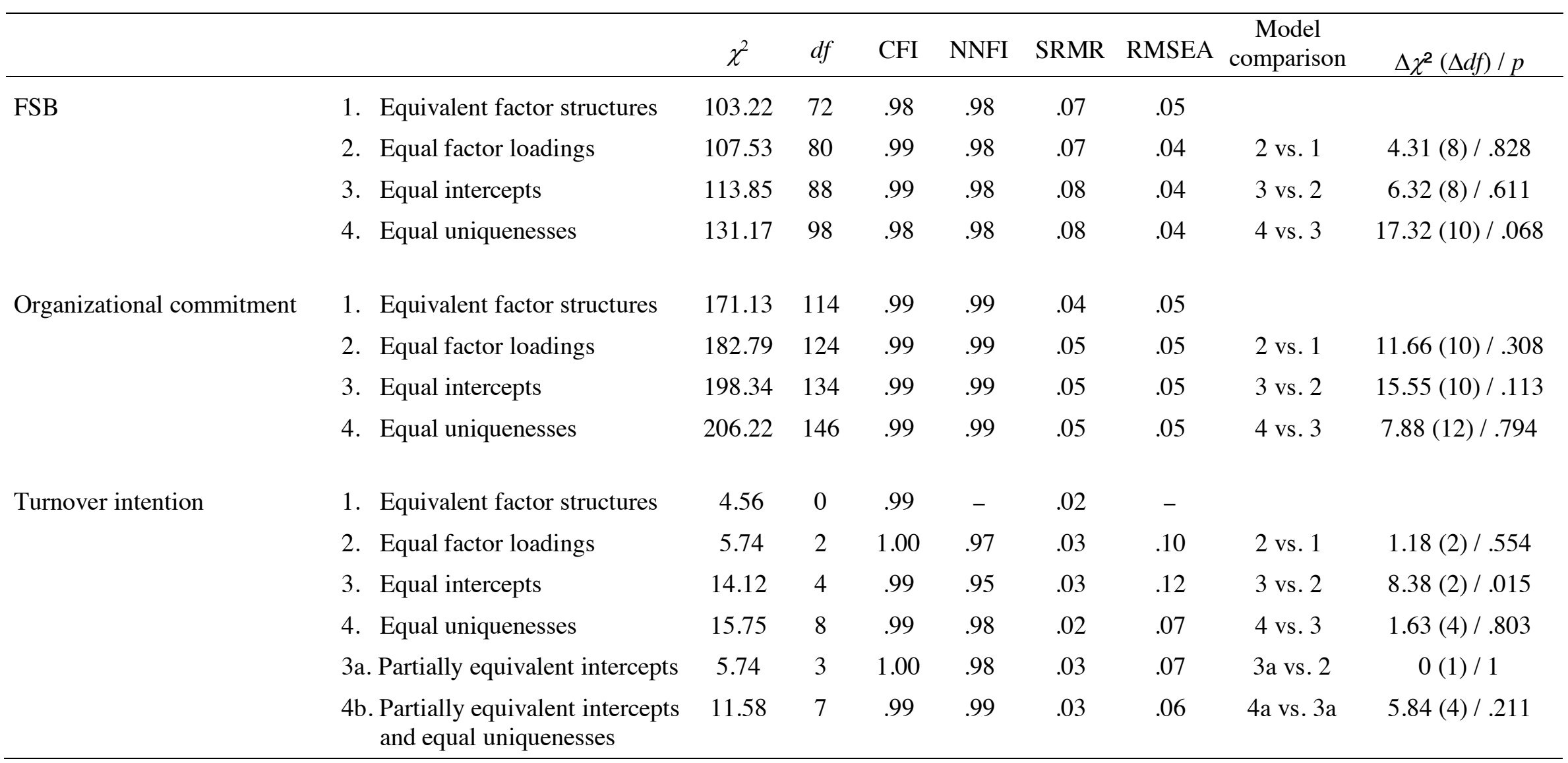

Note. $N=170$. Models were tested using LISREL 8.54 (Jöreskog et al., 2001). FSB = Feedback-seeking behavior; CFI $=$ Comparative fit index; NNFI = Nonnormed fit index; SRMR $=$ Standardized root mean square residual; RMSEA = Root mean square error of approximation. 
Table 7

Study 2: Univariate Second-Order Factor Latent Growth Models: Tests of Alternative Specifications

\begin{tabular}{|c|c|c|c|c|c|c|c|c|c|}
\hline & & $\begin{array}{l}\text { Change } \\
\text { function }\end{array}$ & $\begin{array}{c}\text { FOF residuals } \\
\text { structure }\end{array}$ & $\chi^{2}$ & $d f$ & CFI & NNFI & SRMR & RMSEA \\
\hline \multirow[t]{5}{*}{ FSB } & Model 0 & No Change & & 152.37 & 102 & .97 & .97 & .08 & .05 \\
\hline & Model 1a & Linear & Homoscedastic & 131.26 & 101 & .98 & .98 & .08 & .04 \\
\hline & Model 2 & Linear & Heteroscedastic & 131.18 & 99 & .98 & .98 & .08 & .04 \\
\hline & Model 3 & Optimal & Homoscedastic & 131.25 & 100 & .98 & .98 & .08 & .04 \\
\hline & Model 4 & Optimal & Heteroscedastic & 136.85 & 98 & .98 & .98 & .08 & .04 \\
\hline \multirow[t]{5}{*}{ Organizational commitment } & Model 0 & No Change & & 218.89 & 150 & .99 & .99 & .06 & .05 \\
\hline & Model 1a & Linear & Homoscedastic & 207.32 & 149 & .99 & .99 & .05 & .05 \\
\hline & Model 2 & Linear & Heteroscedastic & 206.71 & 147 & .99 & .99 & .05 & .05 \\
\hline & Model 3 & Optimal & Homoscedastic & 207.19 & 148 & .99 & .99 & .05 & .05 \\
\hline & Model 4 & Optimal & Heteroscedastic & 206.22 & 146 & .99 & .99 & .05 & .05 \\
\hline \multirow[t]{5}{*}{ Turnover intention } & Model 0 & No Change & & 93.33 & 11 & .90 & .86 & .10 & .21 \\
\hline & Model 1 & Linear & Homoscedastic & 11.64 & 10 & 1.00 & 1.00 & .04 & .03 \\
\hline & Model 2 & Linear & Heteroscedastic & 11.01 & 8 & 1.00 & .99 & .04 & .04 \\
\hline & Model 3 & Optimal & Homoscedastic & 11.62 & 9 & 1.00 & .99 & .04 & .04 \\
\hline & Model 4 & Optimal & Heteroscedastic & 10.85 & 7 & 1.00 & .99 & .04 & .05 \\
\hline
\end{tabular}

Note. Models were tested using LISREL 8.54 (Jöreskog et al., 2001). FSB = Feedback-seeking behavior; CFI = Comparative fit index; NNFI = Nonnormed fit index; SRMR = Standardized root mean square residual; RMSEA = Root mean square error of approximation.

Retained (most parsimonious) model. 
Table 8

Study 2: Univariate Second-Order Factor Latent Growth Models: Growth Parameters Estimates

\begin{tabular}{|c|c|c|c|c|c|}
\hline \multirow{3}{*}{ Variable / Parameter } & \multicolumn{2}{|c|}{ Initial Status (IS) } & \multicolumn{2}{|c|}{ Change $(\mathrm{CH})$} & \multirow{3}{*}{$\begin{array}{c}\text { Covariance IS-CH } \\
\left(\sigma_{\text {Is.ch }}\right)\end{array}$} \\
\hline & Mean & Variance & Mean & Variance & \\
\hline & $\left(\mu_{\text {Is }}\right)$ & $\left(\sigma^{2}{ }_{\mathrm{is}}\right)$ & $\left(\mu_{\mathrm{cH}}\right)$ & $\left(\sigma_{\mathrm{CH}}^{2}\right)$ & \\
\hline FSB (linear \& homoscedastic) & $2.46 * * *$ & $.18^{* * *}$ & $-.10 * * *$ & $.02 *$ & -.02 \\
\hline Organizational commitment & $3.46 * * *$ & $.69 * * *$ & $-.08 * * *$ & .01 & .00 \\
\hline \multicolumn{6}{|l|}{ (linear \& homoscedastic) } \\
\hline Turnover intention & $2.11 * * *$ & $1.06 * * *$ & $.40 * * *$ & $.18 * *$ & -.10 \\
\hline
\end{tabular}

Note. Models were tested using LISREL 8.54 (Jöreskog et al., 2001). FSB = Feedback-seeking behavior. Standardizing the manifest variables impedes the ability to examine change because the standardization equates the means and variances (Tisak $\&$ Meredith, 1990); therefore, unstandardized estimates are reported.

$* p<.05$

$* * p<.01$

$* * * p<.001$ 
Figure 1

Study 1: Augmented Multivariate SOF LGM model

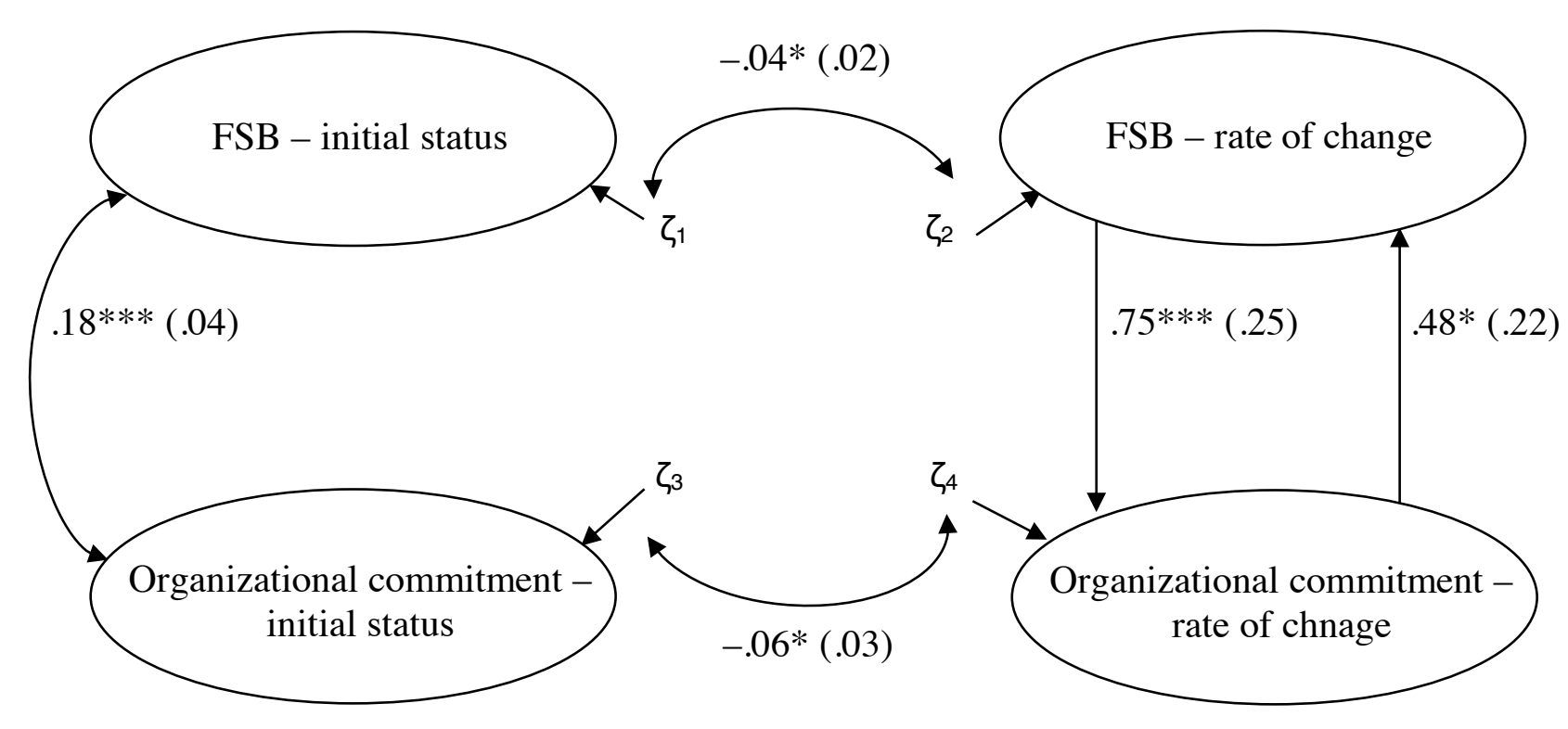

Note. Standardized parameter estimates are reported. Standard errors are reported in parentheses. FSB = Feedback-seeking behavior. For the sake of parsimony, first-order factors and control variables are not represented.

$* p<.05$

$* * * p<.001$ 
Figure 2

Study 2: Augmented Multivariate FOF LGM Model

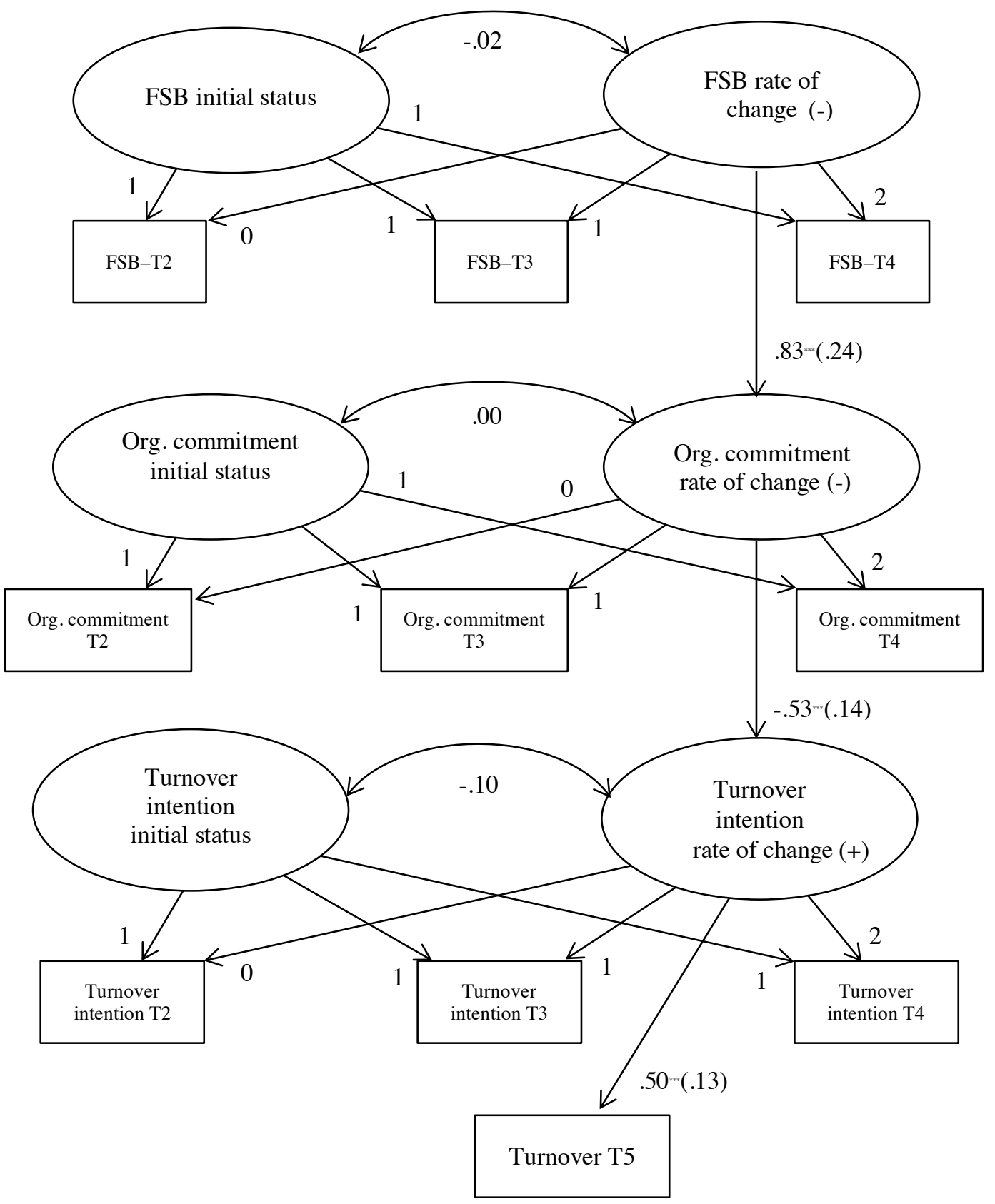

Note. Standardized parameter estimates are reported. Standard errors are reported in parentheses. Fixed covariances are presented. Covariances among exogenous variables are freely estimated but not represented. Time 1 control variables are not represented. Indicators' and items' residuals are not reported. $\mathrm{T} 1=$ Time $1 ; \mathrm{T} 2=$ Time 2; T3 = Time 3; T4 = Time 4; T5 = Time 5; FSB = Feedback-seeking behavior; Org. commitment = Organizational commitment. $* * * p<.001$ 